\title{
CAVE CARABIDAE \\ (COLEOPTERA) OF MAMMOTH CAVE, PART II.
}

\author{
By Thomas C. Barr, JR.
}

\section{Department of Zoology, University of Kentucky, Lexington}

This is a continuation of my account of the Cave Carabidae of Mammoth Cave, the first part of which was published in the preceding issue of Psyche (Volume 73, pp. 284-287).**

$P$. inexpectatus forms the type of an inexpectatus species group, generally distributed eastward and northward from Mammoth Cave. The species are all rather small (less than $4 \mathrm{~mm}$ ) and slender, with unusually elongate, slender aedeagi containing long, slender copulatory pieces. The posterior margin of the last sternite in the males is broken by a distinct notch. The affinities of the inexpectatus group seem to lie with $P$. gracilis Valentine (Giles Co., Virginia), $P$. hadenoecus Barr (Pendleton Co., West Virginia), and undescribed species from Fayette Co., Pennsylvania, and Randolph Co., West Virginia. All of these eastern species are small, have an elongate aedeagus, reflexed at the tip, and have the last sternite of the males notched. The copulatory pieces are considerably shorter, however, than those of the inexpectatus group. In P. horni and related species in the inner Bluegrass of Kentucky there is a slight emargination in the last sternite of the males. Perhaps this indicates an affinity with the inexpectatus group, but the single copulatory sclerite and other morphological characters suggest that horni and its relatives are more closely allied with the audax group.

$P$. pubescens has been taken sporadically at two sites in Mammoth Cave: ( I) Crevice Pit, near the top of Mammoth Dome; and (2) on cave cricket guano near the top of Moonlight Dome in the Frozen Niagara part of the cave. Elsewhere in Mammoth Cave National Park it has been collected in one of two caves in the bottom of Cedar Sink, 4 miles southwest of the Historic Entrance to Mammoth Cave. $P$. pubescens occurs frequently along cave streams, but is not uncommon in certain caves in rather dry areas, where it occurs crawling about on dry silt in the manner of Neaphaenops. It does not appear to show as narrow a degree of habitat selection as mene-

* As a result of a printing error, this part of Professor Barr's article was omitted from his account of the Mammoth Cave Carabidae in the December, 1966, issue of Psyche (pp. 284-287). Since this omission was not discovered until after the copies of the issue had been mailed, the rest of the paper is published here as a continuation of the previous article. [Editor]. 
triesii and striatus, and is possibly a more generalized predator. The pubescens group ranges south and west from Mammoth Cave and the menetriesii group ranges north and east, although the two groups overlap broadly in Edmonson, Hart, Warren, and Barren counties near Mammoth Cave. The two groups are probably distantly related because of the unusual, anterior position of the first discal seta, but the shape of the aedeagus and the structure of the transfer apparatus is quite different in each group.

With these 6 rather closely related species, the Mammoth Cave system has the most diverse trechine fauna of any cave in North America. Sympatry of 2, 3, or even 4 species is not uncommon in certain caves of the Greenbrier Valley of West Virginia or the western margin of the Cumberland plateau in Tennessee and Kentucky. Perhaps more species would be discovered in some of these other caves if they were subjected to the same intensive collecting that Mammoth Cave has enjoyed over the past 125 years. Despite this attention, it is worth noting that $P$. inexpectatus was not discovered in Mammoth Cave until I957, and that $P$. audax has been taken only 3 times in 85 years.

The presence of 6 similar species in the same cave leads naturally to consideration of the principle of competitive exclusion, according to which these species should occupy different niches. From what has already been said about the habitat preferences of $P$. striatus and $P$. menetriesii - the two most closely related species - it seems clear that their niches quite probably overlap but include significant, mutually exclusive components. $P$. pubescens probably bears a similar relationship to each of these two species, since the three coexist syntopically not only in Mammoth Cave but also in Diamond Caverns, Cave City Cave, Walnut Hill Cave, and in various other caves of the Pennyroyal plateau. Its relative rarity in Mammoth Cave has yet to be explained. Neaphaenops tellkampfii feeds heavily on the eggs and nymphs of the cave cricket, Hadenoecus subterraneus (Scudder), although it is not limited to this food. To its exploitation of a food not generally utilized by other trechines may be atributed its occurrence in drier upper galleries, its extraordinary abundance and greater size, its extensive geographical distrivution, and its sympatry in various parts of its range with no less than Io species of Pseudanophthalmus. The peculiar, seasonal occurrence of $P$. inexpectatus (late winter and early spring) and $P$. audax (late summer), and their great rarity could mean that they occupy unusual, as yet unsuspected niches, or that they compete less successfully for the resources of the environment with the other species. 
Acknowledgments: I wish to thank M. S. Ghilarov and K. V. Arnoldi for checking the Motschulsky types in the Zoological Museum of Moscow, T. G. Marsh and R. M. Norton for assistance in collecting, and Superintendent Paul McG. Miller for permission to collect in Mammoth Cave National Park.

Barr, Thomas C., JR.

\section{Literature Cited}

1959. The male of Pseudanophthalmus audax (Coleoptera, Carabidae). Trans. Kentucky Acad. Sci., 20: 1-3.

1962. The blind beetles of Mammoth Cave, Kentucky. American Midl. Nat., $68: 278-284$.

JeAnNel, Rene

1928. Monographie des Trechinae ( $3^{\mathrm{e}}$ livraison). L'Abeille, $35: 1-808$.

1949. Les coléoptères cavernicoles de la région des Appalaches. Notes Biospéol., 4, Publ. Mus. Nat. Hist. Nat., Paris, no. 12: 37-104. Motschulsky, T. Victor voN

1862. Études entomologiques (11 ${ }^{\mathrm{me}}$ Année). Dresden, 55 pp. 

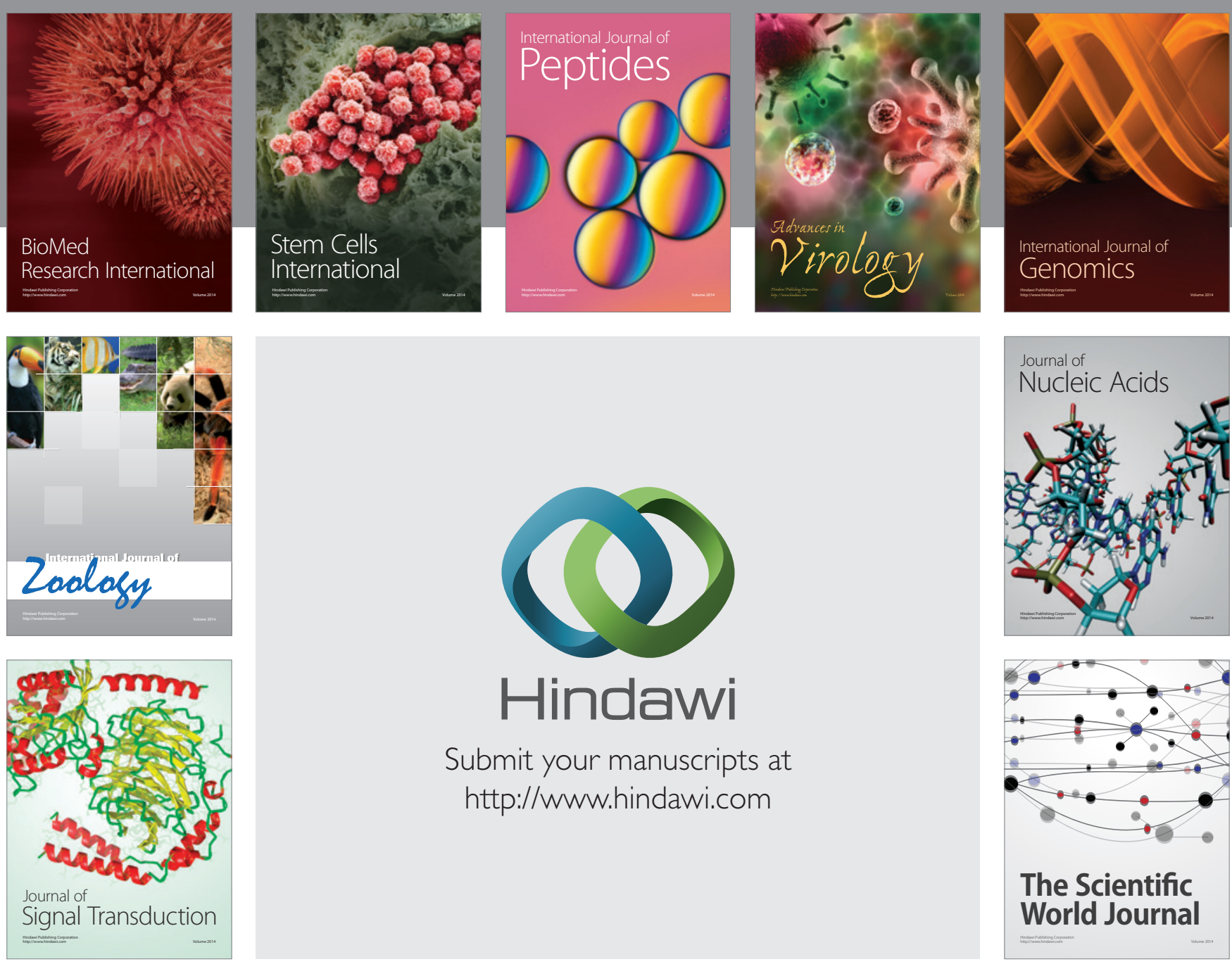

Submit your manuscripts at

http://www.hindawi.com
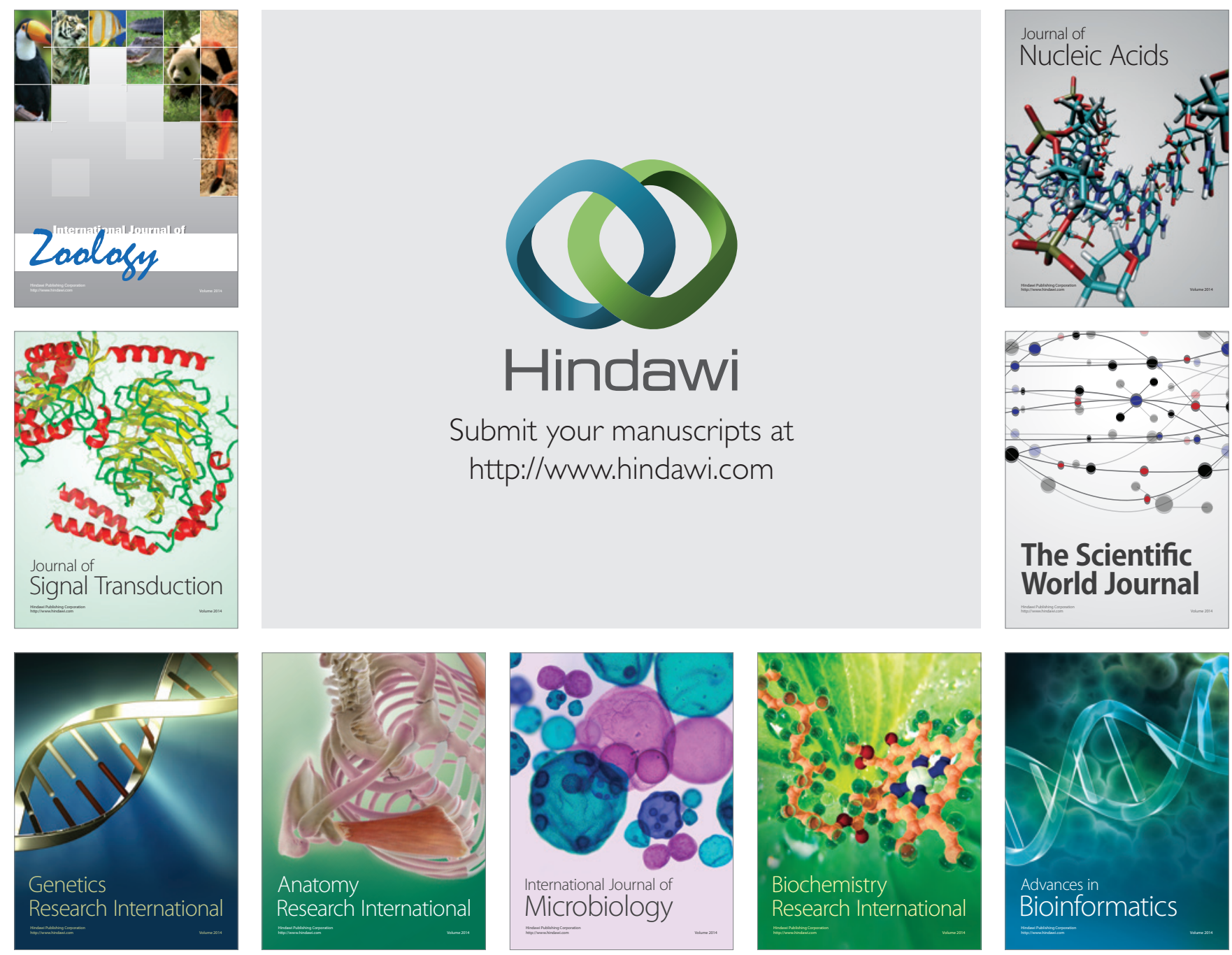

The Scientific World Journal
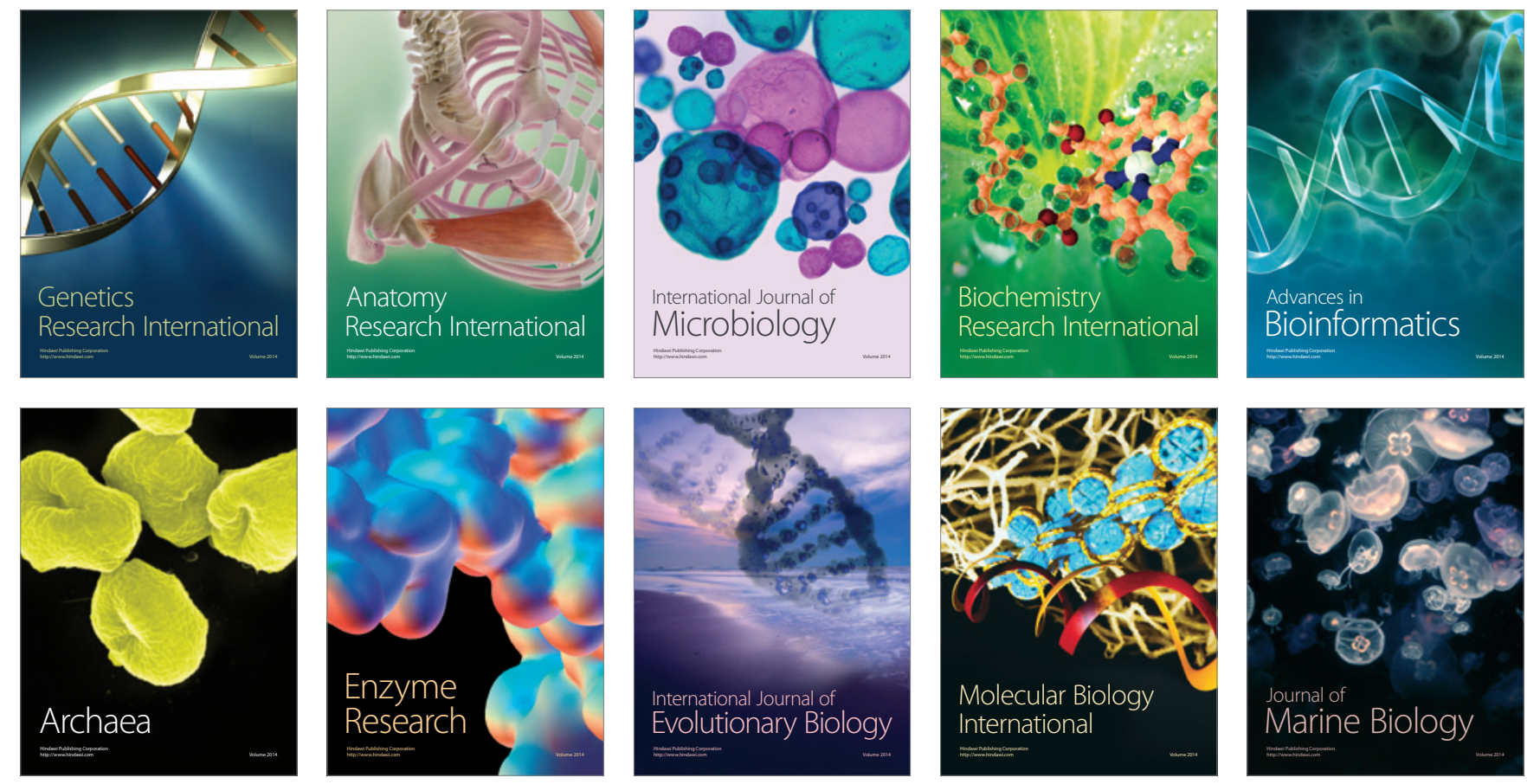